\title{
Interactions of grazing and plant protection on basin big sagebrush (Artemisia tridentata ssp. tridentata) seedling survival
}

\author{
M.K. OWENS AND B.E. NORTON
}

\begin{abstract}
Authors are with Texas A\&M University Agricultural Research and Extension Center, 1619 Garner Field Road, Uvalde 78801; and the Department of Range Science, Utah State University, Logan 84322. At the time of the research Owens was with the Department of Range Science, Utah State University, Logan 84322.
\end{abstract}

\begin{abstract}
The impact of grazing animals and plant protection on shrub seedling establishment was studied in 2 separate experiments. A total of 3,665 seedlings were monitored for survival during a sheep grazing trial in 1984, and 5,755 seedlings were monitored during a cattle grazing trial in 1986. Approximately $1 / 2$ of the seedlings were located under the canopy of mature plants and $1 / 2$ were located in the interspaces between plants. The presence of domestic livestock and the seedling location affected both the overall survival at the end of the growing season and the pattern of survival during the growing season. The interaction between these independent variables resulted in the highest survival $(0.11)$ for sheltered seedlings in the grazed pastures and the lowest survival (0.009) for unprotected seedlings in the grazed pastures. Seedlings in the ungrazed pastures had survival rates intermediate between these 2 rates.
\end{abstract}

The pattern of seedling survival was similar in both experiments. Seedlings in the grazed pastures experienced high mortality during the actual graxing event and immediately after grazing. Seedlings which were unsheltered experienced the lowest survival due to trampling. Survival rates late in the summer were not affected by grazing but were dependent on receiving precipitation during this normally dry period of the year.

The interaction between grazing and seedling location may partially explain the aggregated distribution of Artemisia found in many communities. This aggregation should affect interspecific competition and may play a role in later stages of plant succession within these shrub-dominated communities.

Key words: seedling survival, sagebrush

The increase of shrub populations in grassland communities is a widespread occurrence in a variety of ecosystems (van Vegten 1983, MacDonald and Frame 1988, Archer et al. 1988). Shrub establishment does not occur as an advancing front from undisturbed shrub stands but seems to occur from isolated shrubs remaining in the grass stand. Two examples are basin big sagebrush (Artemisia tridentata spp tridentata) which often invades pastures seeded to grasses such as crested wheatgrass (Agropyron desertorum) from shrubs which were not killed prior to seeding the grass (Marlette and Anderson 1986), and the shrub Baccharis pilularis which invades the annual grasslands of California (Williams et al. 1987).

Native sagebrush is a long-lived shrub which has little value for grazing herbivores. Vast areas associated with long-term heavy

\footnotetext{
This research was supported by the Utah Agricultural Experiment Station, Utah State University, Logan 84322-4845. Approved as journal paper 3456 . The authors wish to thank Drs. D. Pyke and C.A. Call for critical review and helpful suggestions to improve this manuscript.

Manuscript accepted 9 August 1991
}

grazing are now dominated by basin big sagebrush communities, with little forage available for domestic livestock (Young et al. 1990). Periodic treatment of these communities with herbicides or prescribed fires can successfully reduce the dominance of basin big sagebrush and promote herbaceous forage production, but regeneration of the shrub population usually occurs. Understanding the population biology of the expanding shrub population is a critical step in successfully managing these rangelands for cattle production.

Basin big sagebrush establishment does not seem to be limited by seed production, although dispersal distance is usually short (Young 1988). An average stand of basin big sagebrush can produce 50 million seeds per ha annually and a plant can begin producing seed in its second year (Young et al. 1989). Harniss and McDonough (1976) found that basin big sagebrush seed germination rates were high enough to exclude seed germination as a limiting factor in the establishment process for the 3 consecutive years of their study. Establishment remains as an episodic event (Young et al. 1989, West et al. 1979).

Environmental factors, especially precipitation, competition, and seedbed factors, play an important role in the growth of shrub populations. Therefore, factors that alter the environment of individual seedlings may also alter the probability of survival and successful establishment. Factors that could affect seedling survival include grazing by large herbivores, seedling location in relation to other plants, and the interaction between these factors. Grazing may actually promote the establishment of an unpalatable species such as basin big sagebrush by reducing competition from the preferred forage species. Seedling location relative to other plants may affect seedling establishment by either protecting the seedling from grazing or by altering the microenvironment.

This study was designed to answer the following questions concerning the expansion of basin big sagebrush populations into crested wheatgrass communities: (1) Does grazing by domestic livestock increase the probability of seedling survival? (2) Does the location of the seedling relative to mature conspecific plants affect seedling survival? and (3) What is the combined effect of grazing and seedling location on overall survival and the pattern of survival during the growing season?

\section{Materials and Methods}

The study was conducted on the Tintic Research Area (elevation $1,830 \mathrm{~m}$ ) located in the Intermountain region of the western United States $\left(39^{\circ} 53^{\prime} \mathrm{N}\right.$ and $\left.122^{\circ} 03^{\prime} \mathrm{W}\right)$. The study pastures within the Research Area were mechanically treated for brush removal in the early 1950's and seeded to crested wheatgrass. Mean annual precipitation is $374 \mathrm{~mm}$ with $75 \%$ falling from October to May as snow (Wraith et al. 1987). Summer precipitation is highly variable in both intensity and location. Precipitation during the first year of 
the study (1984) was above normal with $452 \mathrm{~mm}$ recorded, while the second year (1986) was about normal with $366 \mathrm{~mm}$.

Two separate experiments were conducted: the first experiment used sheep as the grazing animal in 1984 and the second experiment used cattle in 1986. No seedlings emerged in 1985 due to drought conditions. Basin big sagebrush seedlings were mapped from emergence to the end of the first growing season in permanent plots $(10 \times 10 \mathrm{~cm})$ in both experiments. All surviving seedlings were mapped at 10-day intervals from May to October 1984 and April to July 1986. A severe summer drought in 1986 reduced seedling numbers sufficiently to curtail sampling. The number and location of dead seedlings were recorded at each sample date. The actual mapping procedure has been described elsewhere (Owens and Norton 1989).

In the sheep grazing experiment, grazing was imposed (8 sheep ha $^{-1}$ ) for 4 days, 24-28 May, in 2 replications; 2 ungrazed pastures served as replicated controls. The brief, intense grazing period was typical of short duration grazing management systems advocated for optimum livestock production on these rangelands. The grazed and ungrazed pastures were randomly selected from 12 pastures in a 28-ha area. Seedlings first became evident in late May and mapping began on 22 May 1984. An entire census was completed before grazing began.

In the cattle grazing experiment, grazing was imposed (11 Angus heifers ha ${ }^{-1}$ ) for 2 grazing periods in 2 replications; 2 ungrazed pastures served as replicated controls. The 2 grazing periods, $28-30$ April and 18-20 May, were included as part of a short duration grazing study (Olson et al. 1989). All basin big sagebrush seedlings emerged in a 1-week period and mapping began on 22 April 1986. Grazing began approximately 6 days after seedling emergence.

Each pasture was stratified to delineate areas with seedlings directly under the canopy of mature basin big sagebrush (sheltered treatment) and areas with seedlings in the interspaces between mature plants (unsheltered treatment). Seedlings were considered to be in the interspace if the seedling was not directly under the canopy of a mature basin big sagebrush. Since basin big sagebrush was the only shrub present, seedlings in the interspaces were completely vulnerable to grazing and direct radiation. A total of $\mathbf{4 0}$ plots were used in 1984 and 36 in 1986. Plot selection consisted of marking 4 plots and randomly selecting 1 of those plots for sampling; the other 3 plots were not used. One-half of the plots were placed in each shelter treatment for all experiments.

\section{Data Analysis}

Two separate analyses were conducted within each experiment. The first analysis examined overall survival at the end of the first growing season for each of the grazing and shelter treatments. The second analysis examined the pattern of survival during the growing season. The basis for these analyses was that each plant was observed for mortality at each sampling date. Therefore, each plant had a limited number of outcomes, in that it could be observed to die at any date or remain alive throughout the experiment. Such a sampling design uses cross-classified categorical data and focuses on the individual plant as the sample unit.

Differences in survival at the end of each experiment between grazing and seedling location treatments were tested using categorical data analysis (CDA) with a 0.05 probability level. CDA is the appropriate technique for analyzing cross-classified categorical data such as survival counts (Fienberg 1983) and has been used in other plant survival analyses (e.g., Chambers et al. 1990, Pyke 1990).

A backward elimination technique was used to select the model which best fit the data using the $X^{2}$ and $G^{2}$ statistics. A hierarchy of models was constructed by successively dropping the highest order interaction from the model. If the $X^{2}$ value were not significant, the result would be to fail to reject the model of no significant interac- tion. If the $X^{2}$ were statistically significant, the model would be rejected and the interaction would be included in the final model. The best model was selected as the model with the fewest number of high order interactions and which still fit the data. A more complete description of the partitioning technique can be found in Fienberg (1983).

After the best model had been selected for the data set, logit models were formed to determine the probability of survival for each treatment combination. Independent $2 \times 2$ Chi-square contingency tests were then calculated using the logit values as a mean separation. This technique is analogous to a protected Fishers LSD after an analysis of variance (Owens and Norton 1989).

The second analysis within each experiment tested the pattern of survival during the growing season using maximum likelihood analysis and the multinomial distribution (White 1983). This technique has been widely advocated for wildlife population studies (Brownie et al. 1978, White 1983) but has been used only occasionally in plant population studies (Gardiner 1986, Salihi and Norton 1987, Owens and Norton 1989). Survival rates were estimated over the finite periods of time between samples (10-day) rather than instantaneous rates over the entire growing season. Models were constructed by setting survival rates equal for critical time periods. For instance, to test for the effects of grazing on the pattern of survival, a model was constructed setting survival rates equal for all cohorts of plants, regardless of treatment, during the grazing period. If grazing did not affect survival, a Chi-square analysis would fail to reject the model of equal survival rates. A significant Chi-square value would reject the model and support the conclusion that the survival rates were not equal during the grazing period. If 2 or more models fit the data, the best model was selected using a likelihood ratio test (Brownie et al. 1978, White 1983).

\section{Results}

\section{Sheep Grazing Experiment}

A total of 3,669 seedlings were marked in all treatments (Table 1). Survival was very low with a total of only 73 and 81 seedlings

Table 1. Distribution of alive and dead basin big sagebrush seedlings under $\mathbf{2}$ separate grazing trials in sheltered and unsheltered microsites.

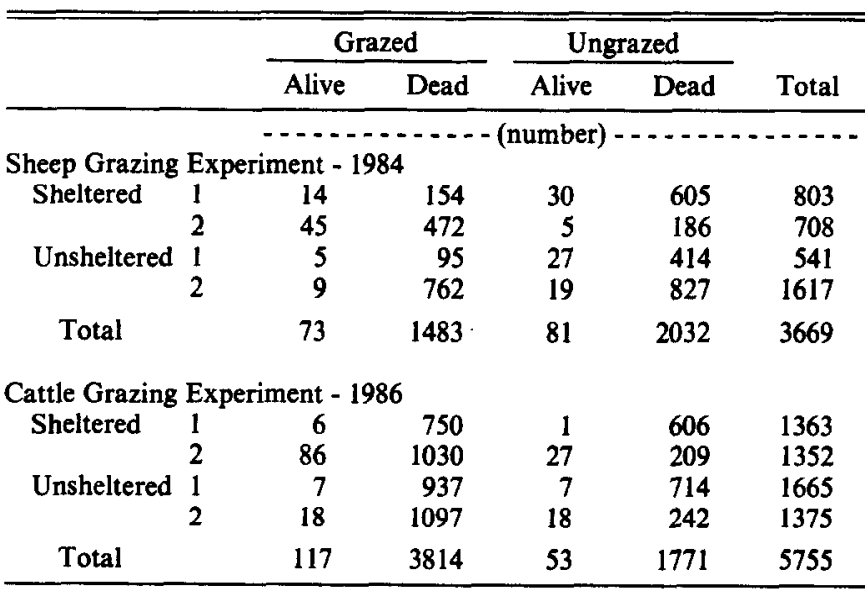

surviving for 1 year from cohorts of 1,556 and 2,113 in the sheepgrazed and ungrazed pastures. Sheltered seedlings experienced higher survival ( 94 alive from 1,511 total) than unsheltered seedlings $(60$ alive from 2,158$)$. None of the seedlings were alive in the spring of 1986.

CDA indicated the best model for the data included the replication $\times$ shelter and grazing $\times$ shelter interactions (Table 2). The $G^{2}$ partitioning indicated that the replication $\times$ shelter interaction was 
Table 2. Categorical data analysis of basin big sagebrush seedling survival. The $\mathrm{X}^{2}$ analysis indicates the significance of the overall model and the $\mathrm{G}^{2}$ analysis indicates the significance of the specific effect.

\begin{tabular}{|c|c|c|c|c|}
\hline \multirow[b]{2}{*}{ Effect } & \multicolumn{2}{|c|}{$\begin{array}{l}\text { Significance } \\
\text { tests of } \\
\text { heirarchical } \\
\text { models }\end{array}$} & \multicolumn{2}{|c|}{$\begin{array}{c}\text { Partitioned } \mathbf{G}^{2} \\
\text { within } \\
\text { the best } \\
\text { fit model }\end{array}$} \\
\hline & $\mathrm{X}^{2}$ & df & $\mathbf{G}^{2}$ & df \\
\hline Grazing & $43.38^{* *}$ & 5 & 3.37 & 1 \\
\hline Shelter & $45.93 * *$ & 4 & $15.13^{* *}$ & 1 \\
\hline Grazing $\times$ Shelter & $12.18^{* *}$ & 5 & $11.52^{* *}$ & 1 \\
\hline Replication $\times$ Shelter & $6.86^{*}$ & 2 & $3.92^{*}$ & 1 \\
\hline Replication $\times$ Grazing & 1.78 & 2 & 0.21 & 1 \\
\hline$\underset{\times \text { Shelter }}{\text { Replication } \times \text { Grazing }}$ & 1.66 & 1 & 1.63 & 1 \\
\hline
\end{tabular}

$\because P<0.05$

$* * P<0.01$

barely significant at $\alpha=0.05\left(G^{2}=3.92, \alpha=0.04\right)$ and that the critical term was the interaction between grazing and shelter $\left(\mathbf{G}^{2}=\right.$ $11.52, \alpha=0.001$ ). The interaction was apparent because seedling location did not affect survival in the ungrazed pastures but did

A) Sheep grazing experiment
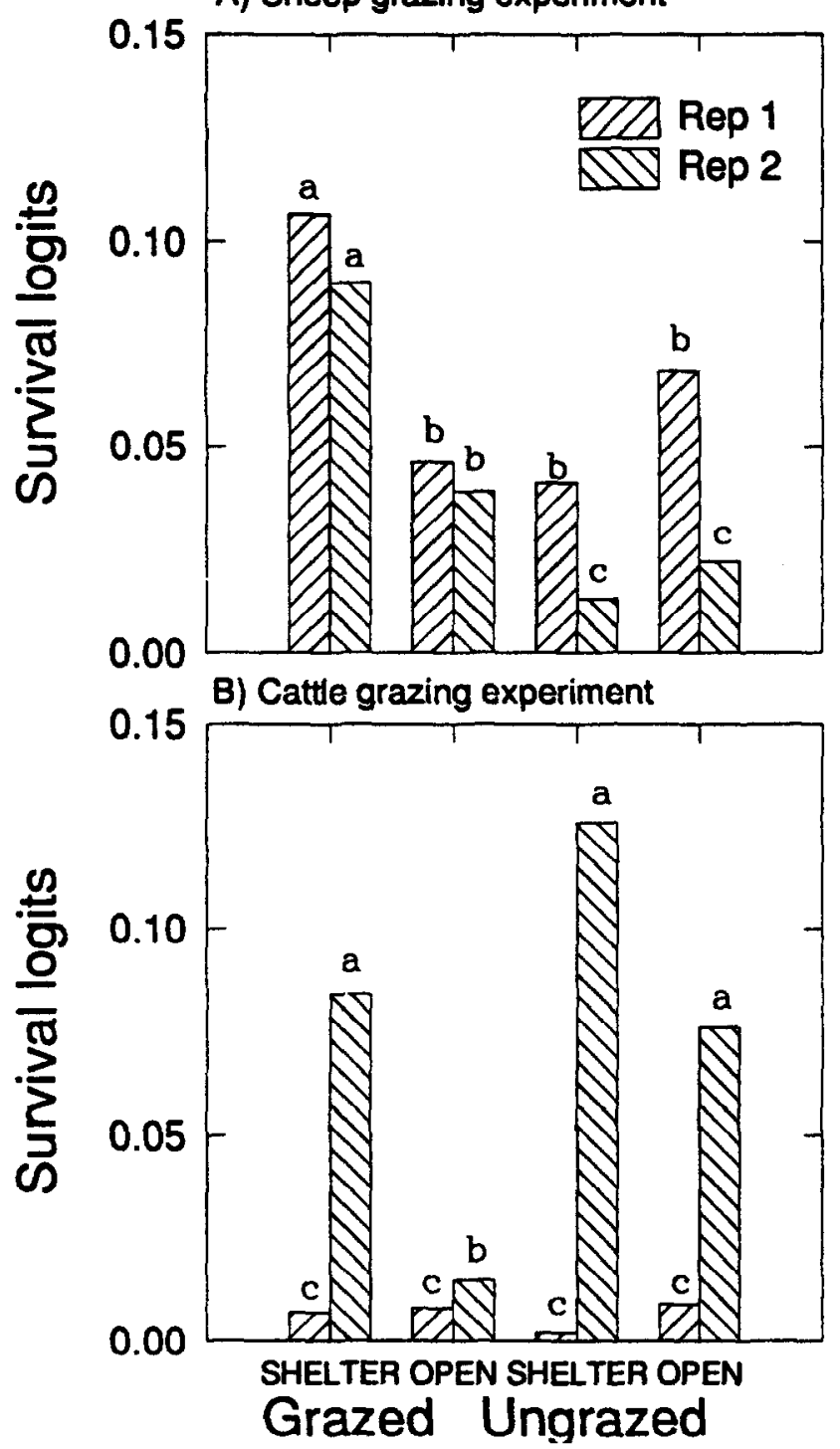

Fig. 1. Mean survival logits for basin big sagebrush seedlings at the end of the first growing season in relation to A) sheep and B) cattle grazing and seedling location. Bars with different letters within an experiment were significantly different at $P<0.05$. affect survival in the grazed pastures (Fig. 1 A). Sheltered seedlings in the grazed pastures had significantly higher logit values than seedlings in any other treatment and unsheltered seedlings had the lowest logit values. Grazing, as a main effect, did not significantly affect survival $\left(G^{2}=3.37\right.$, Table 2$)$ because the sheltered and unsheltered seedlings were combined to test for this main effect.

The pattern of seedling survival in the sheep grazing experiment was evaluated to investigate the relationships between grazing and seedling shelter. Survival during the grazing period (relativized to 10 days) was significantly lower in the grazed pastures for the unsheltered and sheltered seedlings than in the ungrazed pastures (Table 3). This difference in seedling survival rates continued for only 10 days following grazing (Fig. 2). For the next 30 days, survival rates were not significantly affected by either the grazing treatment or seedling location.
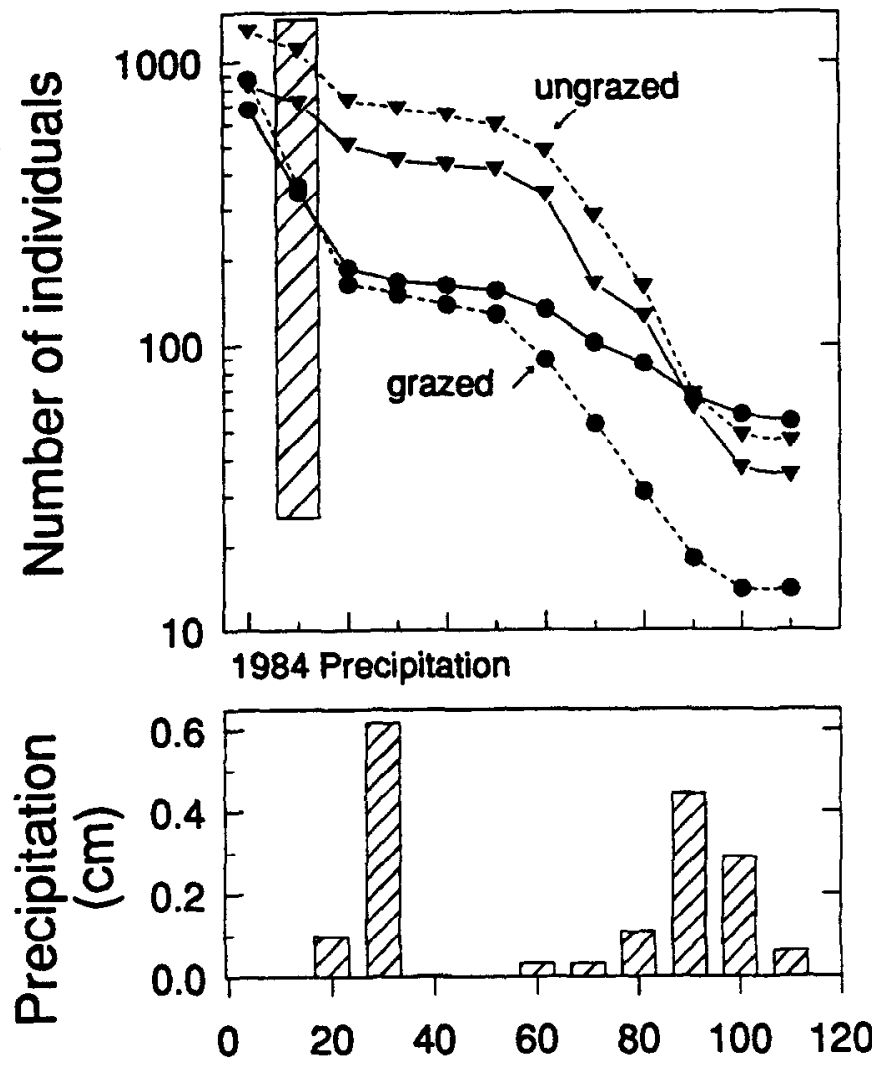

\section{Days after emergence}

Fig. 2. Basin big sagebrush seedling survival in pastures grazed by sheep (circles) and in ungrazed controls (triangles). Seedlings were in sheltered (solld lines) and unsheltered (dashed lines) locations. Hatched area represents the actual grazing period of 24-28 May 1984. Precipitation is presented as 10-day totals.

A summer drought began approximately 30 days after emergence and continued for about 50 days (Fig. 2). At the beginning of the drought ( 60 days after emergence), seedling survival rates in the grazed, sheltered treatment were slightly higher than for the other treatments (Table 3). As the summer drought progressed, survival rates for the seedlings in grazed, sheltered treatment were significantly higher than for seedlings in any of the other treatments.

\section{Cattle Grazing Experiment}

A total of 5,755 seedlings were mapped in the cattle grazing experiment (Table 1). Survival was low with only 117 and 53 seedlings surviving from cohorts of 3,931 and 1,824 in the grazed and ungrazed treatments. Survival was slightly higher in the shel- 
Table 3. Probabilities of seedling survival in sheltered and unsheltered microsites during a 110 day sheep grazing trial.

\begin{tabular}{|c|c|c|c|c|c|c|c|c|c|c|c|c|}
\hline & & \multicolumn{11}{|c|}{ Days after emergence } \\
\hline & & $10^{*}$ & 20 & 30 & 40 & 50 & 60 & 70 & 80 & 90 & 100 & 110 \\
\hline \multicolumn{13}{|l|}{ Grazed } \\
\hline \multirow[t]{2}{*}{ Sheltered } & $\bar{x}$ & 0.18 & 0.42 & 0.83 & 0.96 & 0.94 & 0.86 & 0.74 & 0.83 & 0.85 & 0.91 & 0.99 \\
\hline & se & 0.02 & 0.03 & 0.04 & 0.02 & 0.02 & 0.03 & 0.04 & 0.04 & 0.03 & 0.03 & 0.01 \\
\hline \multirow[t]{2}{*}{ Unsheltered } & $\bar{x}$ & 0.11 & 0.32 & 0.87 & 0.89 & 0.90 & 0.69 & 0.56 & 0.55 & 0.71 & 0.85 & 1.00 \\
\hline & se & 0.01 & 0.03 & 0.03 & 0.03 & 0.03 & 0.04 & 0.05 & 0.07 & 0.07 & 0.07 & 0.01 \\
\hline \multicolumn{13}{|l|}{ Ungrazed } \\
\hline \multirow[t]{2}{*}{ Sheltered } & $\bar{x}$ & 0.71 & 0.61 & 0.80 & 0.95 & 0.95 & 0.81 & 0.45 & 0.75 & 0.63 & 0.74 & 0.99 \\
\hline & se & 0.02 & 0.02 & 0.02 & 0.01 & 0.01 & 0.02 & 0.03 & 0.04 & 0.04 & 0.05 & 0.01 \\
\hline \multirow[t]{2}{*}{ Unsheltered } & $\bar{x}$ & 0.68 & 0.56 & 0.90 & 0.92 & 0.89 & 0.81 & 0.55 & 0.52 & 0.59 & 0.81 & 0.99 \\
\hline & se & 0.02 & 0.02 & 0.01 & 0.01 & 0.01 & 0.02 & 0.02 & 0.03 & 0.03 & 0.04 & 0.01 \\
\hline
\end{tabular}

* Grazing occurred during this time period.

tered treatment ( 120 survivors from a cohort of 2,715$)$ than in the unsheltered treatment ( 50 survivors from 3,040 seedlings).

CDA indicated the best model included all of the 2-way interactions between replications, grazing treatment, and shelter (Table 4).

Table 4. Categorical data analysis of basin big sagebrush seedlings during the cattle grazing experiment. The $\mathrm{X}^{2}$ statistic indicates the significance of the overall model and the $G^{2}$ analysis indicates the significance of the specific model.

\begin{tabular}{|c|c|c|c|c|}
\hline \multirow[b]{2}{*}{ Effect } & \multicolumn{2}{|c|}{$\begin{array}{l}\text { Significance } \\
\text { tests of } \\
\text { heirarchical } \\
\text { models }\end{array}$} & \multicolumn{2}{|c|}{$\begin{array}{l}\text { Partitioned } \mathrm{G}^{2} \\
\text { within the } \\
\text { best fit } \\
\text { model }\end{array}$} \\
\hline & $X^{2}$ & df & $\mathrm{G}^{2}$ & $\mathrm{df}$ \\
\hline Grazing & $29.72^{* *}$ & 4 & $10.77^{* *}$ & 1 \\
\hline Shelter & $53.22 * *$ & 4 & $35.19 * *$ & 1 \\
\hline Grazing $\times$ Shelter & $9.71 * *$ & 2 & $9.31 * *$ & 1 \\
\hline Replication $\times$ Shelter & $8.34^{* *}$ & 2 & $8.03^{* *}$ & 1 \\
\hline Replication $\times$ Grazing & $13.12 * *$ & 2 & $12.30^{* *}$ & 1 \\
\hline $\begin{array}{l}\text { Replication } \times \text { Grazing } \\
\times \text { Shelter }\end{array}$ & 0.38 & 1 & 0.40 & 1 \\
\hline
\end{tabular}

$* P<0.05$

$* P<0.01$

The $G^{2}$ partitioning of the model demonstrates that all of the effects are statistically significant within this model. The interaction of replications with the other factors was due to the near total mortality found in the first replication (Fig. 1B). There were no significant differences between the logit values in the first replication and the values were generally very small. Seedlings in an unsheltered location in the grazed pastures had the lowest probability of survival while protected seedlings had the highest chances for survival in both grazed and ungrazed pastures in the second replication. Seedlings without the protection of mature basin big sagebrush were 5 times more likely to die in the grazed pasture than in the ungrazed pasture. Within grazed pastures, the difference was more pronounced, with protected seedlings being up to 6 times more likely to survive than unprotected seedlings (Fig. 1B). In the other replication, over $99 \%$ mortality in all treatments precluded the detection of treatment effects.

As with the sheep study, grazing by cattle caused differences in the pattern of mortality during the 80-day trial (Fig. 3). During the first 2-day grazing period, survival rates were significantly higher for the ungrazed seedlings in the sheltered $(0.91)$ and unsheltered $(0.85)$ microsites than in the same microsites in the grazed pastures ( 0.84 and 0.49 , respectively, Table 5 ). During the second grazing period 18 days later, survival was much lower in all treatments but survival was significantly lower in the grazed, unsheltered treat-
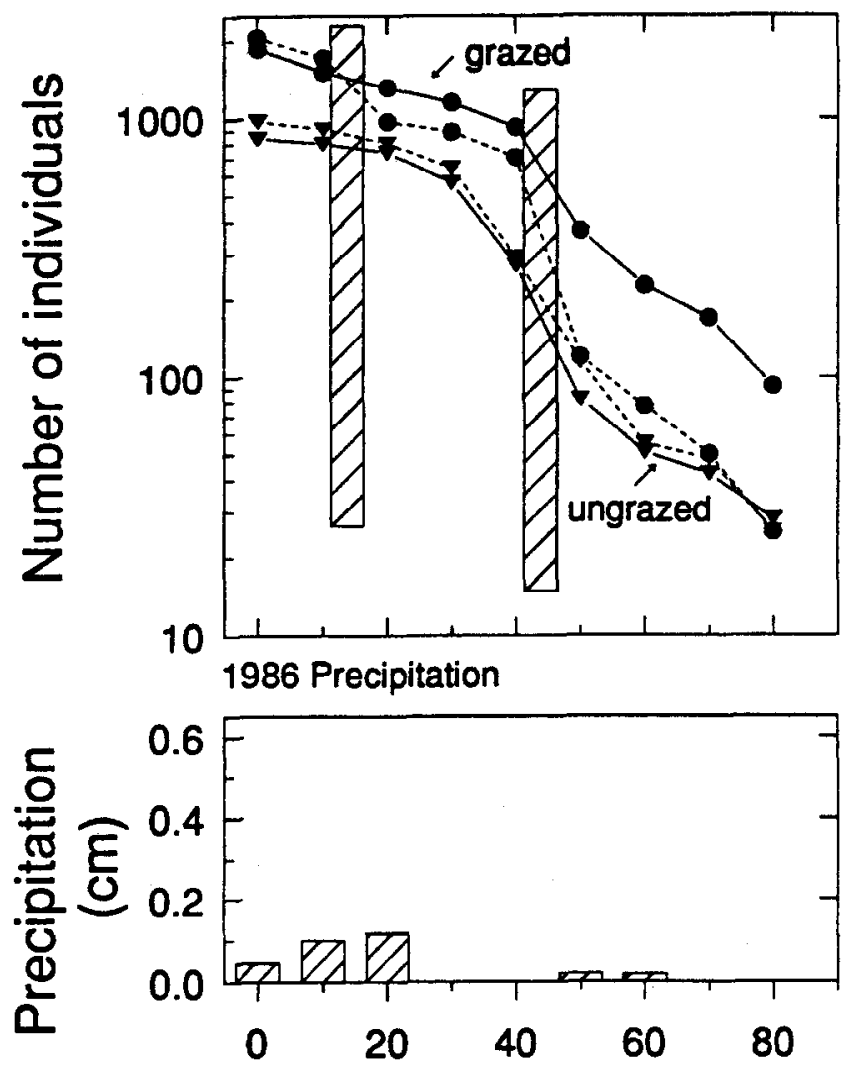

Days after emergence

Fig. 3. Basin big sagebrush seedling survival in pastures grazed by cattle (circles) and in ungrazed controls (triangles). Seedlings were in sheltered (solid lines) and unsheltered (dashed lines) locations. Hatched areas represent the actual grazing periods of 28-30 April and 18-20 May 1986. Precipitation is presented as 10-day totals.

ment than in any other treatment. A dry period began 20 days after seedling emergence and continued throughout the summer (Fig. 3). Seedling survival in all treatments decreased as the dry summer progressed, but survival in the ungrazed pastures was sharply depressed during the period of 10 to 20 days after the beginning of the summer drought ( 40 days after emergence, Table 4 ).

\section{Discussion}

Grazing by domestic livestock or native herbivores has been reported to decrease seedling survival of some shrubs and grasses (Eckert et al. 1986, Gardiner 1986, Salihi and Norton 1987) but 
Table 5. Probabilities of seedling survival in sheltered and unsheltered microsites during a cattle grazing trial.

\begin{tabular}{|c|c|c|c|c|c|c|c|c|c|}
\hline & \multicolumn{9}{|c|}{ Days after emergence } \\
\hline & & 10 & $20^{*}$ & 30 & 40 & $50^{*}$ & 60 & 70 & 80 \\
\hline \multicolumn{10}{|l|}{ Grazed } \\
\hline \multirow[t]{2}{*}{ Sheltered } & $\bar{x}$ & 0.81 & 0.84 & 0.85 & 0.69 & 0.27 & 0.54 & 0.56 & 0.67 \\
\hline & se & 0.01 & 0.01 & 0.01 & 0.02 & 0.02 & 0.03 & 0.04 & 0.03 \\
\hline \multirow[t]{2}{*}{ Unsheltered } & $\bar{x}$ & 0.84 & 0.49 & 0.89 & 0.68 & 0.08 & 0.57 & 0.42 & 0.63 \\
\hline & se & 0.01 & 0.01 & 0.01 & 0.02 & 0.01 & 0.05 & 0.07 & 0.06 \\
\hline \multicolumn{10}{|l|}{ Ungrazed } \\
\hline \multirow[t]{2}{*}{ Sheltered } & $\bar{x}$ & 0.95 & 0.91 & 0.71 & 0.29 & 0.18 & 0.55 & 0.68 & 0.76 \\
\hline & se & 0.01 & 0.01 & 0.02 & 0.02 & 0.02 & 0.06 & 0.09 & 0.06 \\
\hline \multirow[t]{2}{*}{ Unsheltered } & $\vec{x}$ & 0.93 & 0.85 & 0.76 & 0.26 & 0.27 & 0.40 & 0.76 & 0.65 \\
\hline & se & 0.01 & 0.01 & 0.02 & 0.02 & 0.03 & 0.05 & 0.08 & 0.06 \\
\hline
\end{tabular}

"Grazing occurred during this time period.

may have a slight positive effect on survival of other species (West et al. 1979). Grazing by either sheep or cattle sharply depressed basin big sagebrush seedling survival for a brief time after the short but intense grazing period (Fig. 2 and 3). Later in the season the remaining seedlings were less prone to mortality than seedlings in the ungrazed pastures. The effects of grazing, evident early in the season, were masked at the end of the season by the late summer moisture-dependent mortality. The net result was no difference in overall seedling mortality between the grazed and ungrazed pastures at the end of the growing season. The seedlings that were not killed from trampling during the grazing period experienced high mortality rates from another source, late summer drought. This is in direct contrast to crested wheatgrass seedlings in the same pastures as this study (Salihi and Norton 1987). The effects of grazing on crested wheatgrass seedling survival, following a similar 2-day grazing period, an 18-day rest and an additional 2-day grazing period, was evident up to 1 year after grazing. For both crested wheatgrass and basin big sagebrush, the individual seedlings were too small to be grazed but were subjected to trampling. Almost $90 \%$ of the crested wheatgrass seedlings occurred in the interspaces rather than under mature plants and may have been more vulnerable to trampling than the basin big sagebrush seedlings in this study. Only $60 \%$ of the basin big sagebrush seedlings in this study were in the interspaces so potential trampling would have been less. Balph et al. (1989) state that vegetation cues are used by cattle to avoid trampling on mature plants, therefore seedlings in the interspaces would be at a higher risk of mortality.

The differential seedling survival rates caused by the sheltered and unsheltered microsites and the presence or absence of grazing may partially explain the aggregated plant distribution found within some semiarid communities (Brown and Archer 1989, Archer et al. 1988). The short dispersal distance (generally $<1 \mathrm{~m}$ ) and favorable microenvironment found beneath mature basin big sagebrush shrubs are also major factors causing aggregation (Young 1988). However, survival rates of seedlings were not affected by the microsites in this study unless the pastures were grazed. The beneficial attributes of increased water holding capacity and nutrient status (Young 1988) did not change survival rates of first-year seedlings. The combined effect of microsites and grazing emphasized the aggregated dispersion pattern. Another arid land shrub, Gutierrezia microcephala, also demonstrates an aggregated dispersion pattern which may be related to differential survival rates for seedlings in various microsites (Parker 1982). Survival rates of Gutierrezia seedlings were generally higher in the vicinity of adult plants than in the interspaces. Herbivores were also a very important influence on survival and distribution of shrub seedlings in that system.

Parker (1982) reported that large seedlings of Gutierrezia microcephala were more likely to die from herbivory and small plants were likely to die from summer desiccation. Since basin big sagebrush seeds were small and emergence was synchronous in this study, with all seedlings emerging within 1 week, plant size was very similar and could not affect the observed survival rates. Grazing sharply reduced the number of seedlings in the grazed pastures, but desiccation resulting from summer drought caused late summer mortality (Fig. 2). In 1986, the lack of late summer rains in August had a marked effect on mortality rates compared to the steady decline in seedling numbers through the relatively moist late summer of 1984 (Fig. 3). This would support the hypothesis that the timing of precipitation is as important as the total amount (Hennessy et al. 1984). Ungrazed annual grasses in California transpired water in the top portion of the soil and prevented Baccharis pilularis shrubs from becoming established unless spring precipitation was relatively high (Williams and Hobbs 1989). The high basin big sagebrush survival noted for sheltered seedlings in the grazed pastures may be affected by this phenomenon. We hypothesize that the heavily grazed grasses in this study were transpiring less water than the ungrazed grasses and that consequently more soil moisture was available for the basin big sagebrush seedlings. Grazed crested wheatgrass plants did not use water as quickly as ungrazed plants on this study site, which would have maintained a more favorable soil water status in the grazed pastures (Wraith et al. 1987).

If grazing is limiting seedling distribution to areas under the protection of mature plants, at some point in the future intraspecific competition may limit either growth or survival. Although the water-holding capacity of the soil is higher under the canopy of basin big sagebrush shrubs, the potential competition between mature shrubs and seedlings is great (Young 1988). Competition may be expressed early, as with Cirsium vulgare which can inhibit seedling growth with litter from mature plants (de Jong and Klinkhamer 1985), or may not be expressed for several years. The aggregated distribution of juvenile basin big sagebrush found on this site suggests that intraspecific competition may play a more important role between juveniles rather than seedlings (Owens 1987). The resultant aggregation of seedlings and juveniles in the grazed pastures may affect intraspecific competition as the plants become larger. Density-dependent mortality of juvenile sagebrush may become an important factor regulating population size and hence establishment rates of shrubs into grasslands.

\section{Literature Cited}

Archer, S., C. Scifres, C.R. Bassham, and R. Maggio. 1988. Autogenic succession in a subtropical savanna: Conversion of grassland to thorn woodland. Ecol. Mono. 58:111-127.

Balph, D.F., M.H. Balph, and J.C. Malechek. 1989. Cues cattle use to avoid stepping on crested wheatgrass tussocks. J. Range Manage. 42:376-377. 
Brown, J.R., and S. Archer. 1989. Woody plant invasion of grasslands: establishment of honey mesquite (Prosopis glandulosa var. glandulosa) on sites differing in herbaceous biomass and grazing history. Oecologia 80:19-26.

Brownie, C., D.R. Anderson, K.P. Burnham, and D.S. Robson. 1978. Statistical inference for ban recovery data-a hand book. U.S. Dept. Interior Fish and Wildl. Serv. Resour. Pub. 131. Washington, D.C.

Chambers, J.C., J.A. MacMahon, and R.W. Brown. 1990. Alpine seedling establishment: the influence of disturbance type. Ecology 71:1323-1341.

de Jong, T.J., and P.G.L. Klinkhamer. 1985. The negative effects of litter of parent plants of Cirsium vulgare on their offspring: autotoxicity or immobolization?. Oecologia 65:153-160.

Eckert, R.E., F.F. Petersen, and J.T. Belton. 1986. Relation between ecological-range condition and proportion of soil-surface types. $J$. Range Manage. 39:409-414.

Fienberg, S.E. 1983. The analysis of cross-classified categorical data. MIT Press, Cambridge, Mass.

Gardiner, H.G. 1986. Dynamics of perennial plants in the mulga (Acacia anueura F. Muell.) zone of western Australia. II. Survival of perennial shrubs and grasses. Australian Range. J. 8:28-35.

Harniss, R.O., and W.T. McDonough. 1976. Yearly variation in germination in three subspecies of big sagebrush subspecies. J. Range Manage. 29:167-168.

Hennessy, J.T., R.D. Gibbens, and M. Cardenas. 1984. The effect of shade and planting depth on the emergence of fourwing saltbush. J. Range Manage. 37:22-24.

MacDonald, I.A.W., and G.W. Frame. 1988. The invasion of introduced species into nature reserves in tropical savannas and dry woodlands. Biol. Conserv. 44:67-93.

Marlette, G.M., and J.E. Anderson. 1986. Seed banks and propagule dispersal in crested wheatgrass stands. J. Appl. Ecol. 23:161-175.

Olson, K.C., G.B. Rouse, and J.C. Malechek. 1989. Cattle nutrition and grazing behavior during short-duration-grazing periods on crested wheatgrass range. J. Range Manage. 42:153-157.

Owens, M.K. 1987. Recruitment of big sagebrush (Artemisia tridentata Nutt. subsp. tridentata) into a seeded foothill rangeland in Utah. Ph.D. Diss. Utah State Univ., Logan, Utah.
Owens, M.K., and B.E. Norton. 1989. The impact of 'available area' on Artemisia tridenta seedling dynamics. Vegetatio 82:155-192.

Parker, M.A. 1982. Association with mature plants protects seedlings from predation in an arid grassland shrub, Gutierrezia microcephala. Oecologia 53:276-280.

Pyke, D.A. 1990. Comparative demography of co-occurring introduced and native tussock grasses: persistence and potential expansion. Oecologia 82:537-543.

Salihi, D., and B.E. Norton. 1987. Survival of perennial grass seedlings under intensive grazing in semi-arid rangelands. J. Appl. Ecol. 24:145-153.

van Vegten, J.A. 1983. Thornbush invasion in a savanna ecosystem in eastern Botswana. Vegetatio 56:3-7.

West, N.E., K.H. Rea, and R.O. Harniss. 1979. Plant demographic studies in sagebrush-grass communities of southeastern Idaho. Ecology 70 376-388.

White, G.C. 1983. Numerical estimation of survival rates from bandrecovery and biotelemetry data. J. Wildl. Manage. 47:716-728.

Williams, K., and R.J. Hobbs. 1989. Control of shrub establishment by springtime soil water availability in an annual grassland. Oecologia 81:62-66.

Williams, K., R.J. Hobbs, and S.P. Hamburg. 1987. Invasion of an annual grassland in northern California by Baccharis pilularis ssp. consanguinea. Oecologia 72:461-465.

Wraith, J.M., D.A. Johnson, R.J. Hanks, and D.V. Sisson. 1987. Soil and plant water relations in a crested wheatgrass pasture: response to spring grazing by cattle. Oecologia 73:573-578.

Young, J.A. 1988. Seedbeds as selective factors in the species composition of rangeland communities. In: P.T. Tueller (ed). Vegetation science applications for rangeland analysis and management. Kluwer Academic Publ. Boston.

Young, J.A., R.A. Evans, and D.E. Palmquist. 1989. Big sagebrush (Artemisia tridentata) seed production. Weed Science 37:47-53.

Young, J.A., R.A. Evans, and D.E. Palmquist. 1990. Soil surface characteristics and emergence of big sagebrush seedlings. J. Range Manage. 43:358-366. 